\title{
PERANCANGAN SISTEM INFORMASI BIMBINGAN KONSELING YANG TERKONEKSI DENGAN WA GATEWAY
}

\author{
Ladias Hutagalung', Yogi Bachtiar², Millati Izzatillah ${ }^{3}$ \\ ${ }_{1,2,3}$ Universitas Indraprasta PGRI \\ Jl. Raya Tengah No. 80, Kel. Gedong, Kec. Pasar Rebo, Jakarta Timur 13760, Jakarta \\ 11.
}

\begin{abstract}
ABSTRAK
MTs Al-Husna Depok merupakan lembaga pendidikan yang bimbingan dan konselingnya masih menggunakan praktik pencatatan pelanggaran siswa, pencatatannya di Microsoft Excel yang dapat mengakibatkan kehilangan data dan pelaporan pelanggaran kepada orang tua melalui surat yang biasanya tidak tersampaikan. Tujuan dari penelitian adalah untuk merancang dan menerapkan suatu sistem informasi bimbingan konseling yang terkoneksi dengan Wa gateway yang dapat membantu dan mempermudah guru bimbingan dan konseling MTs Al-husna dalam menangani pelanggaran siswa di sekolah dan mempercepat pelaporan pelanggaran siswa kepada orang tua siswa dengan terkoneksinya WA gateway. Sistem ini digunakan dengan framework Bootstrap, Node.js, bahasa pemrograman Javascript, VS Code, XAMPP dan MySQL. Metodologi penelitian yang digunakan adalah penelitian dengan studi lapangan dimana untuk pengambilan data, yaitu melalui pengamatan langsung, wawancara dengan pihak terkait, serta melakukan studi pustaka untuk mendapatkan informasi yang dibutuhkan. Hasil dari penelitian ini adalah adanya suatu perangkat aplikasi yang dibuat dengan bahasa pemrograman Javascript yang menggunakan framework Bootstrap dan penyimpanan data menggunakan database dari MySQL. Dalam membangun sistem ini, digunakan alat bantu perancang sistem yaitu dengan metode UML (Unified Modeling Language). Sistem yang dirancang ini dapat mempermudah guru bimbingan konseling dalam proses pendataan siswa yang bermasalah dan memberi laporan kepada orang tua siswa melalui WA gateway.
\end{abstract}

Kata Kunci: Sistem Informasi, Bimbingan Konseling, WA Gateway dan MySQL.

\begin{abstract}
MTs Al-Husna Depok is an educational institution whose guidance and counseling still uses the practice of recording student violations, recording in Microsoft Excel which can result in data loss and reporting of violations to parents through letters that are usually not delivered. The purpose of the research is to design and implement a counseling guidance information system connected to wa gateway that can help and facilitate teachers guidance and counseling MTs Al-husna in dealing with student violations in school and speed up the reporting of student violations to parents of students with connected WA gateway. The system is used with bootstrap, node.js, javascript programming languages, VS Code, XAMPP and MySQL. The research methodology used is research with field studies where for data retrieval, namely through direct observation, interviews with related parties, and conducting literature studies to get the information needed. The result of this research is the existence of an application device created with javascript programming language that uses the Bootstrap framework and data storage using databases from MySQL. In building this system, system designer tools are used with the UML (Unified Modeling Language) method. This designed system can make it easier for guidance teachers to counsel in the process of collecting troubled students and report to parents of students through WA gateway.
\end{abstract}

Key Word: Information Systems, Counseling Guidance, WA Gateway and MySQL.

\section{PENDAHULUAN}

Teknologi informasi merupakan salah satu kemajuan teknologi yang berkembang pesat, oleh karena itu kebutuhan akan informasi dapat dimanfaatkan dalam berbagai bidang, antara lain bidang pendidikan, khususnya bimbingan dan konseling sekolah.

Bimbingan dan Konseling (BK) merupakan bagian dari keseluruhan sistem pendidikan, khususnya di sekolah. Sebagai komponen utama pelaksana rencana pendidikan, guru bertanggung jawab untuk mendukung pelaksanaan rencana pendidikan sekolah dan perlu memahami konsep dasar bimbingan sekolah dan konseling.

Secara pribadi, ada banyak kemungkinan potensi bagi siswa yang dapat dikembangkan. Akan tetapi tidak semua menyadari potensi yang dimiliki dan memahami untuk mengembangkannya. Dalam hal ini guru BK merupakan salah satu orang yang paling berpengaruh dalam mendewasakan anak didik 
agar menjadi anggota keluarga, masyarakat, bangsa yang berguna dan memiliki kepribadian yang mencerminkan akhlak mulia (Susanto, 2018).

WhatsApp (WA) Gateway adalah sistem aplikasi yang digunakan untuk mengirim dan menerima pesan WhatsApp dari Internet atau aplikasi lain ke perangkat WhatsApp lainnya. Dengan Whatsapp gateway, setiap perangkat dan aplikasi dapat terhubung ke perangkat WhatsApp untuk bertukar informasi dan data dengan yang berperan dalam koneksi ini, yaitu Application Programming Interface (API).

Sistem bimbingan dan konseling yang dilakukan di MTs Al-Husna Depok masih menggunakan pencatatan pelanggaran yang dengan Microsoft Excel yang rawan dapat mengakibatkan kehilangan data dan pelaporan pelanggaran siswa kepada orang tua yang secara manual. Salah satu contohnya dengan memberikan surat panggilan orang tua melalui siswa tersebut yang kemungkinan tidak tersampaikan kepada orang tua siswa tersebut.

Tujuan yang hendak dicapai dalam penelitian ini adalah memberikan solusi dalam menangani pihak sekolah MTs Al-Husna Depok khususnya bagian bimbingan konseling dalam pencarian data siswa bimbingan dan membuat laporan yang cepat dan akurat serta meminimalisir terjadinya masalah-masalah yang terjadi seperti kehilangan data bimbingan konseling siswa dan ketidakakuratan data yang dapat mempengaruhi kualitas dari laporan yang nantinya akan diberikan kepada orang tua yang terkoneksi dengan WA gateway.

Langkah yang pertama dalam membuat sebuah sistem adalah perancangan sistem tersebut. "Perancangan adalah proses pengembangan spesifikasi baru berdasarkan rekomendasi berdasarkan hasil analisis sistem". (Subhan, 2012).

Sistem merupakan sekumpulan elemen yang mengontrol sistem dan memproses input untuk menghasilkan hasil yang diinginkan. (Kristanto, 2018).

Informasi adalah data yang diolah sedemikian rupa sehingga lebih berguna dan bermakna bagi orang yang menerimanya. Data adalah bentuk jamak dari singular atau elamen. Datanya adalah peristiwa yang menggambarkan sesuatu yang sedang terjadi pada saat ini. (Yakub, 2012).

Perancangan sistem informasi adalah tahap selanjutnya selesainya analisa sistem informasi, menerima gambaran dengan jelas dengan apa yang dikerjakan dalam sistem informasi, maka dilanjutkan dengan memikirkan bagaimana menciptakan sistem informasi tersebut.

Berdasarkan dari uraian di atas penulis tertarik membuat suatu "Perancangan Sistem Informasi Bimbingan Konseling Yang Terkoneksi Dengan WA Gateway" untuk mempermudah layanan kepada orang tua murid dan pihak sekolah atau guru bimbingan konseling terhadap masalah-masalah siswa yang memiliki masalah disekolah dan juga mempermudah siswa untuk konsultasi kepada guru bimbingan konseling.

\section{METODE PENELITIAN}

Metode penelitian yang dilakukan oleh penulis pada penelitian ini adalah metode penelitian Research and Development yang disingkat dengan R\&D. Research and Development adalah metode penelitian yang digunakan untuk membuat produk tertentu dan menguji kemanjuran produk tersebut. (Sugiyono, 2016)

Langkah-langkah pengembangan sistem yang digunakan penulis dalam pengembangan sistem informasi bimbingan konseling yang terkoneksi dengan WA Gateway dengan menggunakan model waterfall. Tahapan yang terdapat pada model waterfall yaitu mengumpulkan materi, analisis, perancangan aplikasi, membuat aplikasi, implementasi, pengujian dan maintenance.

Rancangan kegiatan dimulai dari bulan Maret 2021 dengan cara melakukan observasi dan wawancara pihak terkait dan studi kepustakaan.

Penelitian dilakukan di Sekolah MTs AlHusna Depok yang terletak di jalan komjen M Jasin No.45 RT.005/RW.003 Kelurahan Tugu Kecamatan Cimanggis, Depok dimulai 
selama 5 bulan Maret tahun 2021 sampai dengan bulan Juli tahun 2021.

Bahasa pemrograman yang digunakan adalah bahasa javascript. JavaScript adalah bahasa pemrograman yang digunakan untuk membuat halaman web tempat pengguna dapat berinteraksi dan merespon peristiwa di halaman tersebut. Javascript adalah perekat yang menyatukan halaman web. (Sianipar, 2017).

Dalam membangun sistem informasi ini dengan javascript diperlukannya framework. Framework adalah kerangka kerja atau sekumpulan record yang sudah ter-include, yang mana di dalam record tersebut terdapat perintah kode application dan fungsi dasar untuk melakukan tugas tertentu. (Yenda, 2016).

Penyimpanan data pada sistem informasi tersebut dengan $M y S Q L$ karena $M y S Q L$ adalah salah satu aplikasi DBMS yang sudah sangat banyak digunakan oleh para pemrogram aplikasi web (Hidayatullah, dkk., 2017).

\section{HASIL DAN PEMBAHASAN}

Berdasarkan hasil penelitian, permasalahan sebelumnya yang terjadi yaitu untuk memberikan pembinaan kepada siswa yang melanggar maka guru BK harus mencatat terlebih dahulu setiap pelanggaran siswa ke dalam microsoft excel kemudian menghitung nilai poin pelanggaran setiap siswa, sering terjadinya laporan panggilan orang tua siswa yang tidak tersampaikan jika menggunakan media surat, dan sering terjadinya ketidaksesuaian atau kehilangan data bimbingan konseling siswa dalam laporan bimbingan konseling.

Berdasarkan permasalahan sebelumnya yang terjadi, peneliti memberikan alternatif penyelesaian masalah, diantaranya .

1. Membuat sistem yang dapat mempercepat proses informasi bimbingan konseling siswa sehingga dapat mempermudah kinerja guru BK dalam menangani siswasiswa bermasalah.

2. Memberikan informasi penyampaian dengan cepat kepada orang tua siswa dengan terkoneksinya sistem dengan WA Gateway.
3. Dapat dimanfaatkan oleh siswa untuk berkonsultasi kepada guru BK tanpa harus bertatap muka.

\section{Usecase Diagram Sistem yang Diusulkan}

Usecase menggambarkan interaksi satu atau lebih entitas dengan sistem informasi yang dibuat.

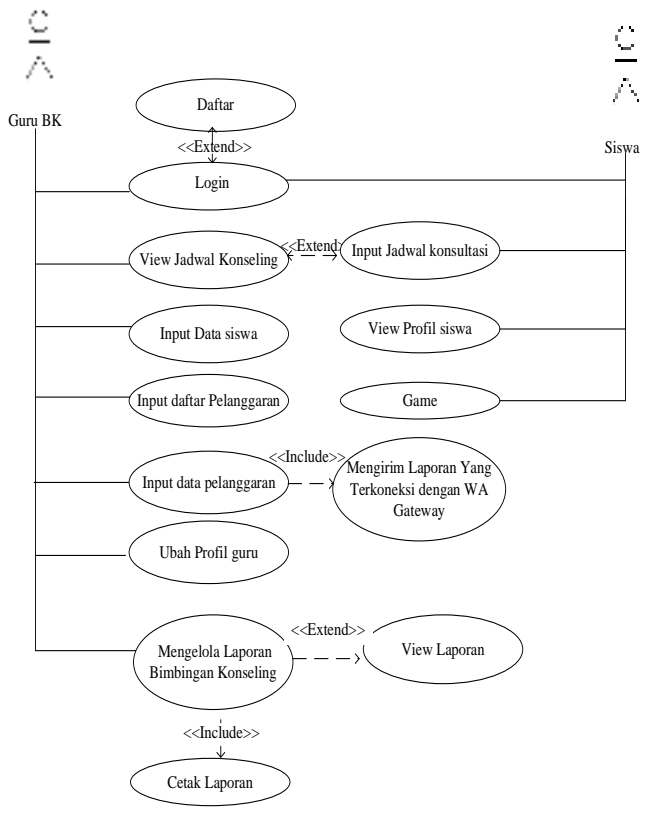

Gambar1. Usecase Diagram

Activity Diagram Sistem yang Diusulkan Diagram aktivitas (workflow) atau aktivitas suatu sistem atau proses bisnis atau menu dalam perangkat lunak. (Rosa \& Shalahuddin, 2018).

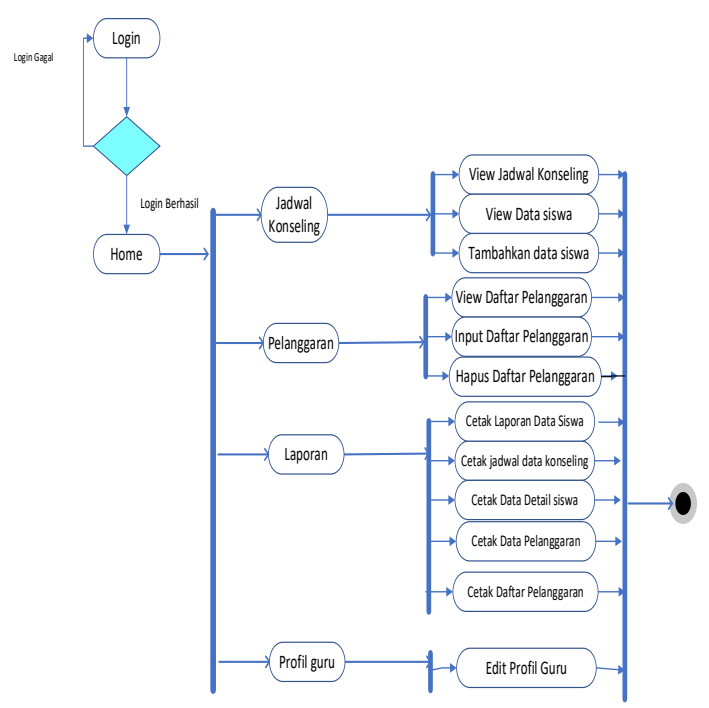

Gambar2. Activity Diagram sebagai guru BK 


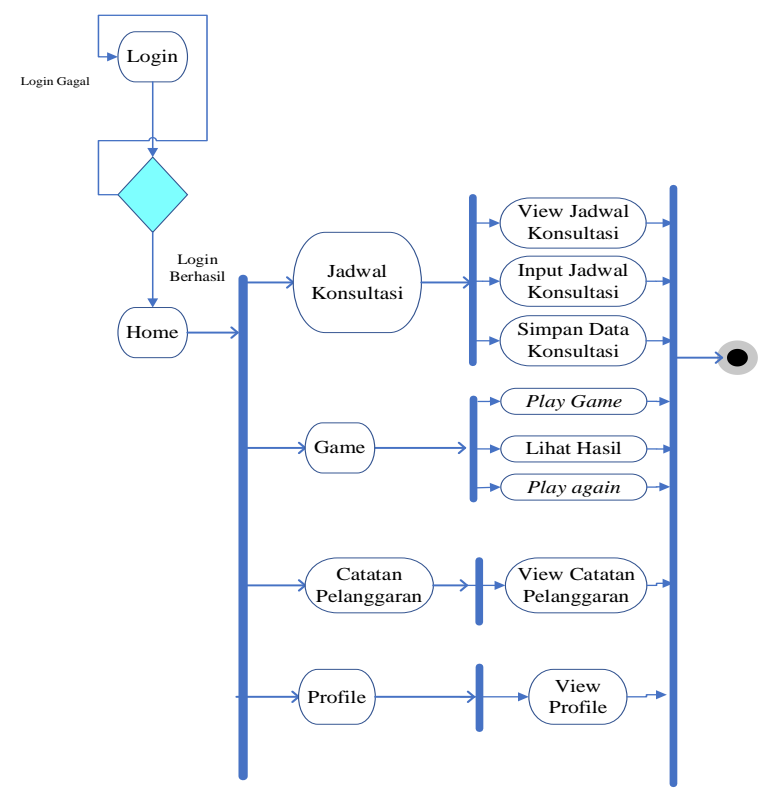

Gambar3. Activity Diagram sebagai siswa

\section{Sequence Diagram Sistem yang Disusulkan}

Diagram urutan menggambarkan prilaku objek dalam usecas, menggambarkan masa hidup suatu objek dan pesan yang dikirim dan diterima antar objek. (Hendini, 2016).

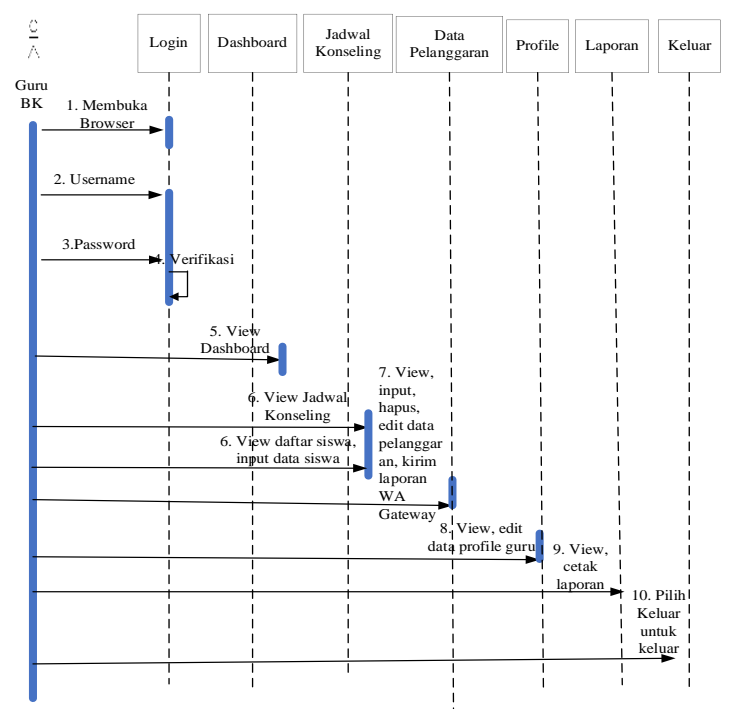

Gambar4. Sequence diagram Guru BK

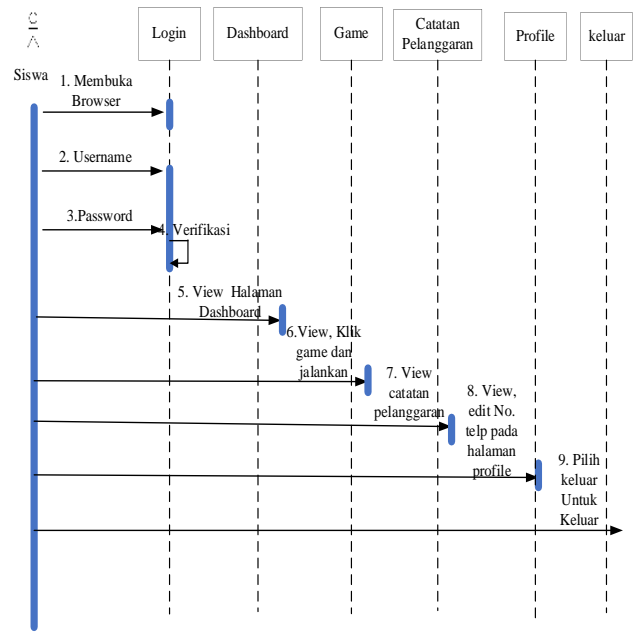

Gambar5. Sequence Diagram sebagai siswa

\section{Class Diagram Sistem yang Diusulkan}

Diagram kelas menggambarkan struktur suatu sistem dengan mendefinisikan kelas-kelas yang akan dibuat untuk membangun sistem tersebut, kelas-kelas yang memiliki atribut dan metode operasi. (Shalahuddin, 2018).

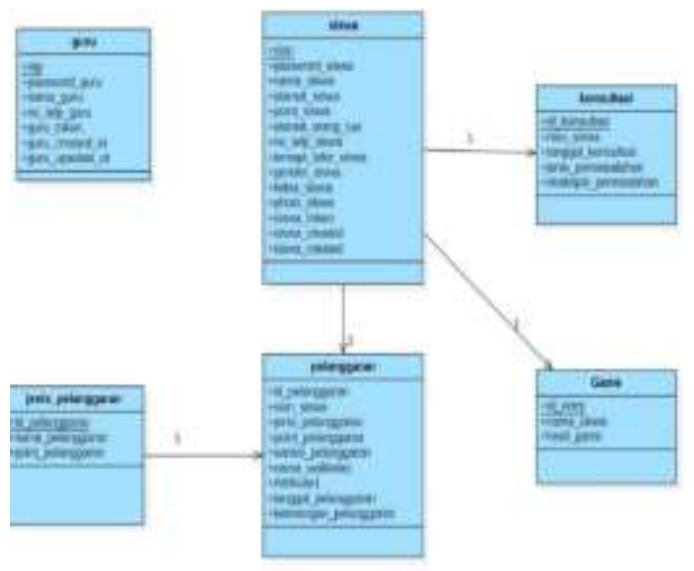

Gambar6. Class diagram

Tampilan Layar Sistem Aplikasi

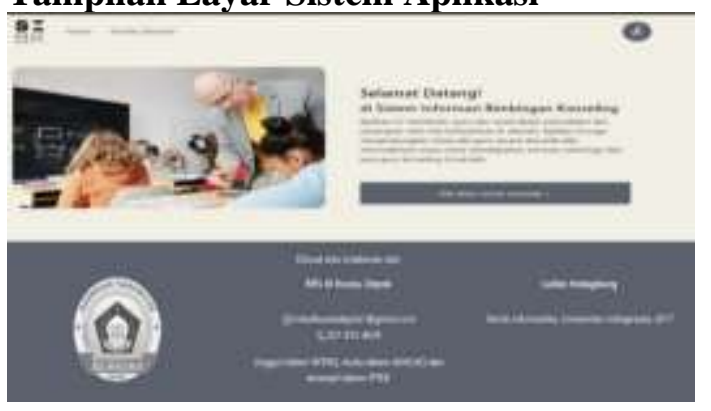

Gambar7. Tampilan Home

Tampilan Home merupakan tampilan yang pertamakali muncul ketika membuka aplikasi sistem informasi bimbingan konseling. 


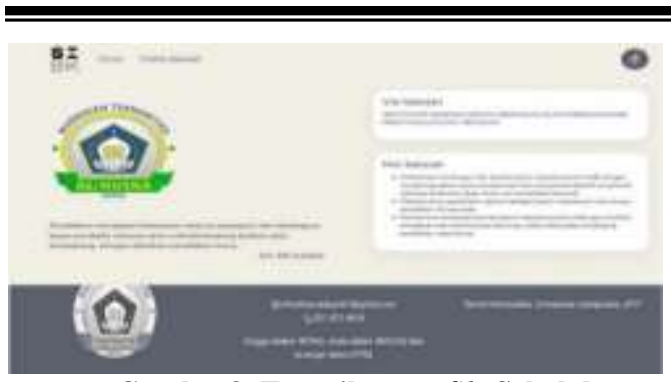

Gambar8. Tampilan Profile Sekolah

Tampilan Profile sekolah menampilkan profile sekolah MTs Al-Husna.

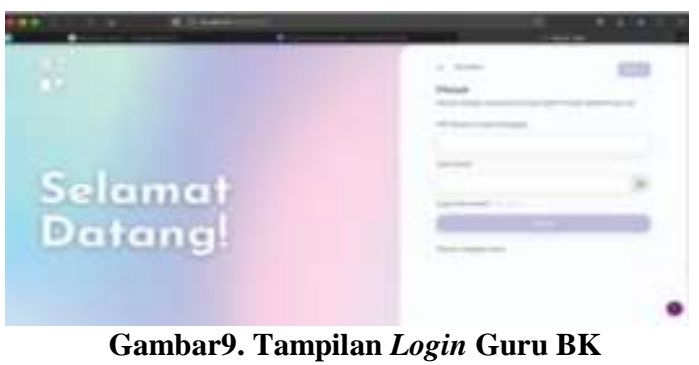

Tampilan login sebagai guru digunakan untuk memulai aktivitas untuk dapat masuk kedalam sistem dengan mengisi username dan password. Dimana username diisikan dengan nip guru.

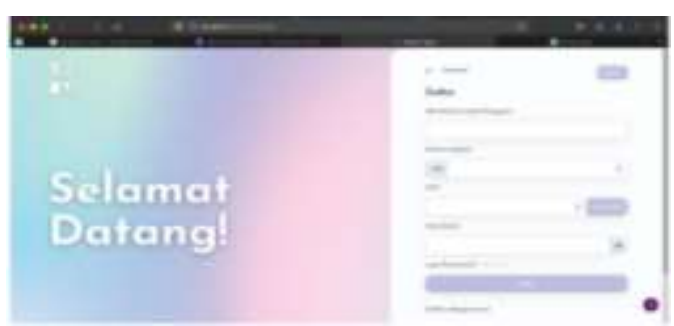

Gambar10. Tampilan Daftar Guru

Tampilan daftar guru berguna untuk mendaftarkan password baru guru supaya dapat masuk kedalam sistem dengan menggunakan username yang sudah ada dan memasukkan no telepon whatsapp untuk mengirim kode otp untuk verifikasi dalam membuat password baru.

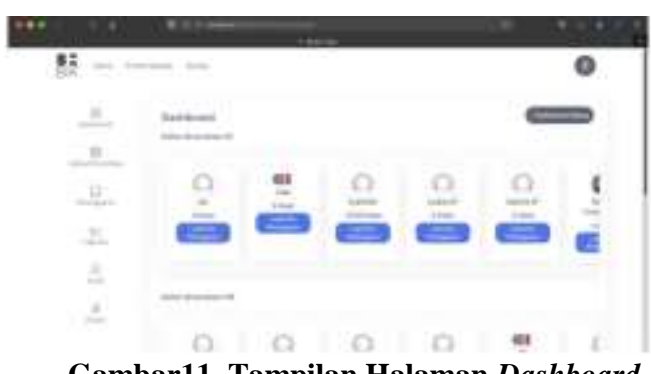

Gambar11. Tampilan Halaman Dashboard

Tampilan halaman dashboard merupakan tampilan yang pertama muncul ketika sudah berhasil login. Pada Tampilan ini menampilkan daftar siswa.

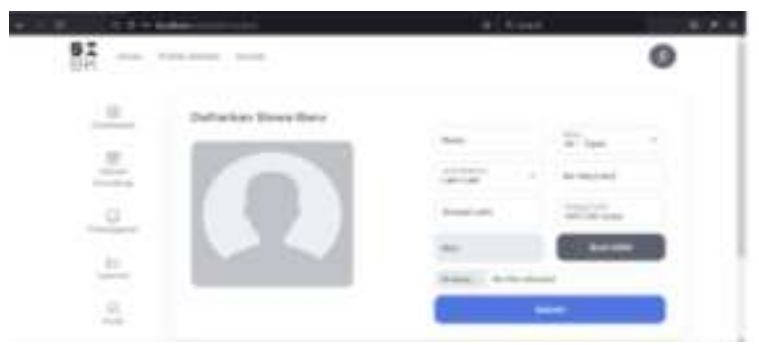

Gambar12. Tampilan Tambah Data Siswa

Tampilan tambah data siswa digunakan untuk menambahkan data siswa dimana data yang diinput adalah nama, nisn, tempat tanggal lahir, no telp dan jenis kelamin.

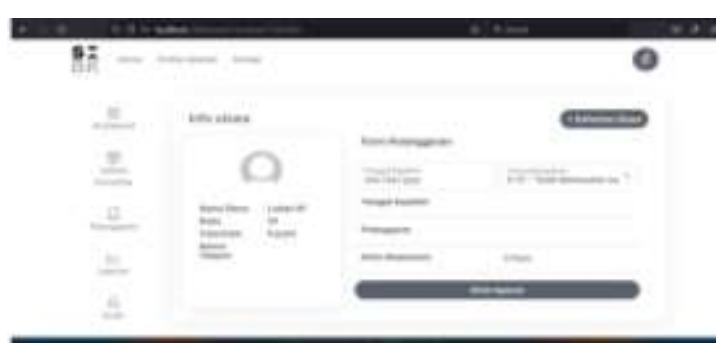

Gambar13. Tampilan Halaman Pelanggaran Siswa

Tampilan halaman pelanggaran siswa digunakan untuk menginput data siswa yang telah melakukan pelanggaran dan langsung melaporkan melalui WA Gateway kepada nomor telepon orang tua yang terkoneksi dengan WhatsApp.

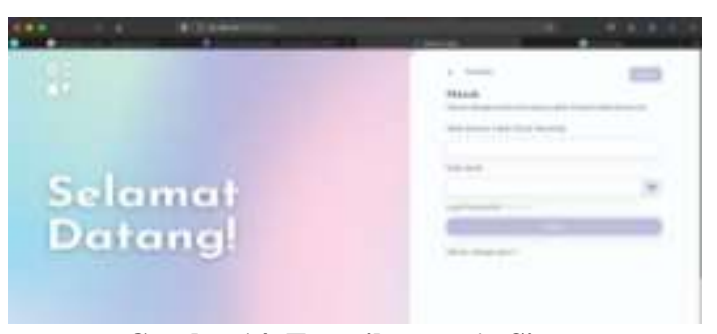

Gambar14. Tampilan Login Siswa

Tampilan login siswa adalah aktivitas pertama yang digunakan untuk masuk ke dashboard siswa, dimana siswa mengisi username dengan nisn siswa dan juga password.

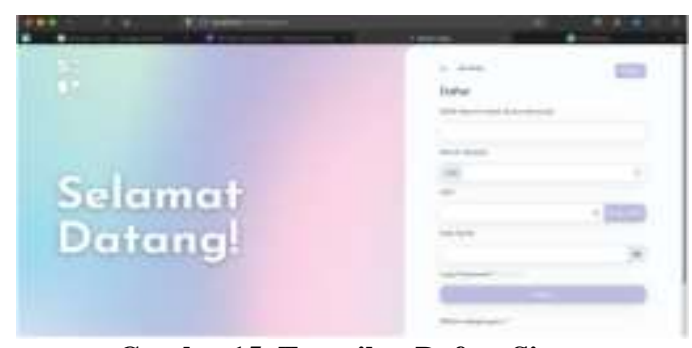

Gambar15. Tampilan Daftar Siswa 
Tampilan daftar siswa digunakan untuk mendaftarkan password siswa namun dengan menggunakan nisn yang sudah terdaftar di sistem dan menggunakan no telepon yang terkoneksi dengan WA untuk mendapatkan kode otp untuk verifikasi kode.

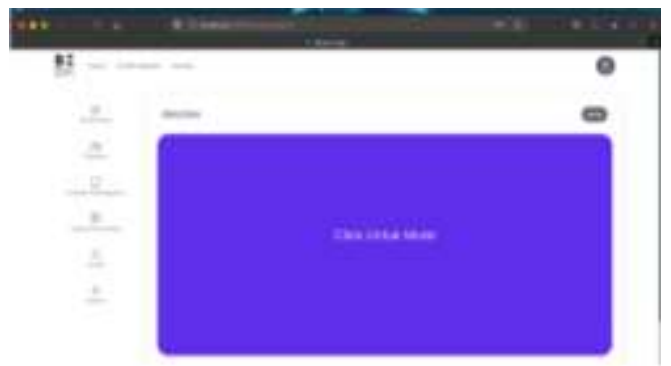

Gambar16. Tampilan Halaman Game Siswa

Tampilan halaman game siswa, siswa dapat mengakses dan mengerjakan tugas yang ada di game.

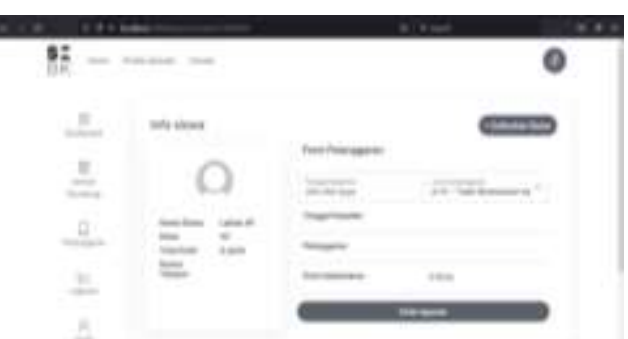

Gambar17. Tampilan Halaman Jadwal Konsultasi

Tampilan halaman jadwal konsultasi menampilkan jadwal siswa untuk konsultasi dan siswa dapat membuat jadwal konsultasi kepada guru bk.

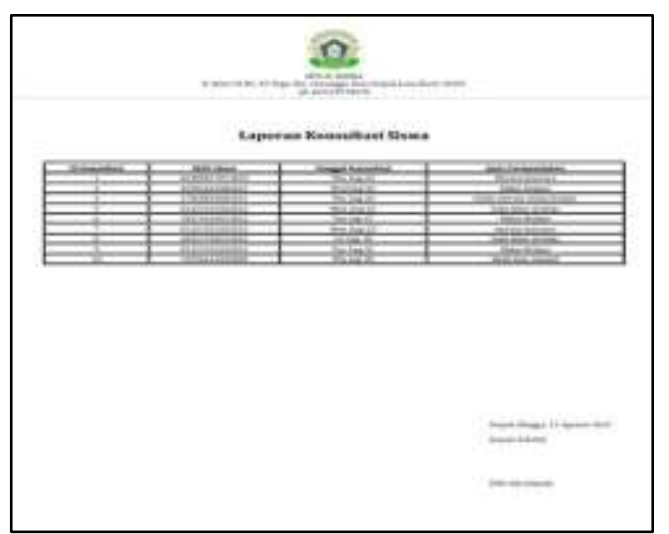

Gambar18. Tampilan Laporan Konseling

Tampilan laporan konseling menampilkan laporan data siswa yang melakukan konseling skepada guru bk yang dicetak.

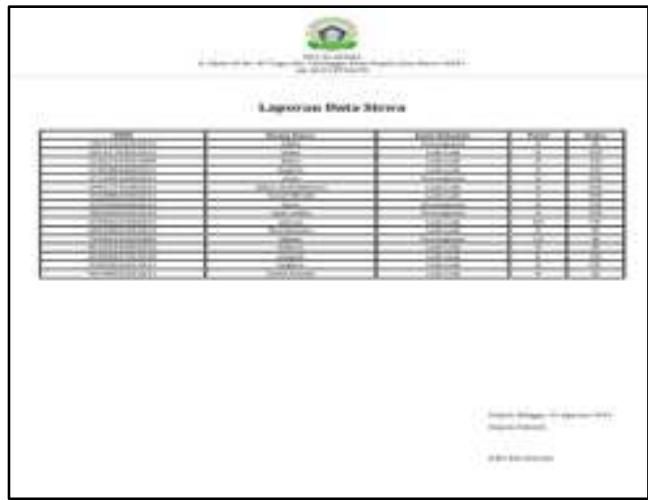

Gambar19. Tampilan Laporan Data Siswa

Pada tampilan data siswa digunakan untuk menampilkan laporan data semua siswa yang dicetak.

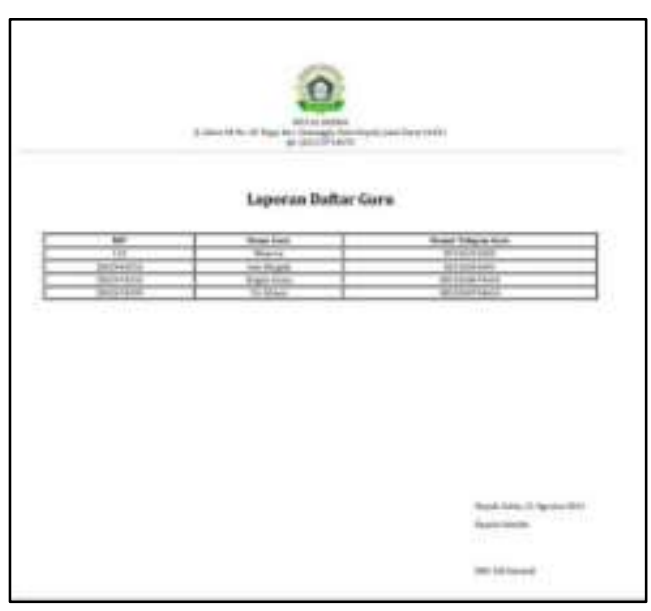

Gambar20. Tampilan Laporan Data Guru

Pada Tampilan ini menampilkan laporan data guru yang dicetak.

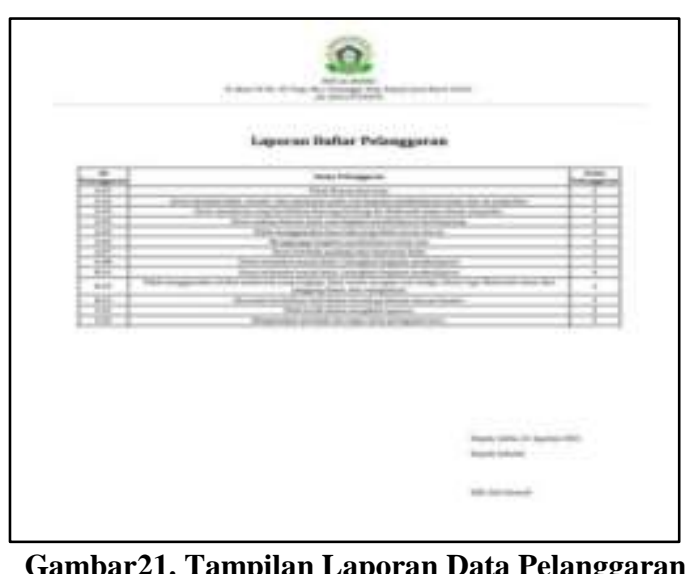

Pada tampilan ini menampilkan data pelanggaran yaitu jenis-jenis pelanggaran yang dicetak. 


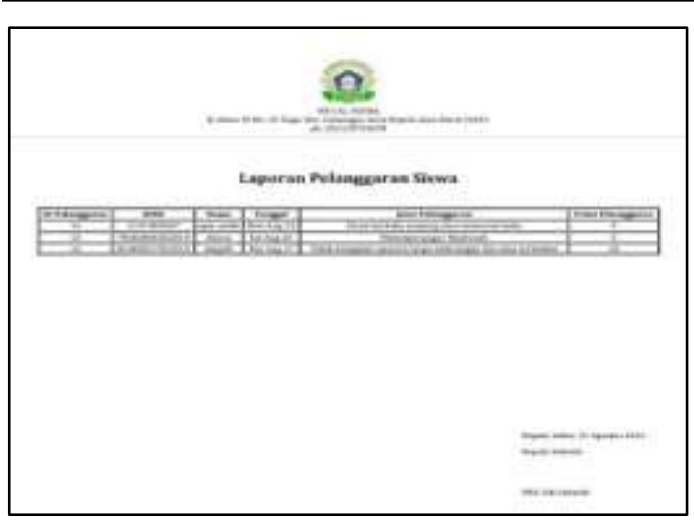

Gambar22. Tampilan Laporan Pelanggaran Siswa

Pada tampilan ini menampilkan laporan data pelanggaran siswa yang melakukan pelanggaran yang dicetak.

\section{SIMPULAN DAN SARAN}

Simpulan dari proses penyusunan penelitian ini serta pembuatan Sistem Informasi Bimbingan Konseling Yang Terkoneksi Dengan WA Gateway, yaitu sebagai berikut:

Sistem informasi ini dibuat dengan bahasa pemrograman javascript dengan Framework Bootstrap, Node JS dan editor VS Code dan tersimpan menggunakan database MySQL. Sistem informasi ini dapat membantu pihak sekolah khususnya bagian bimbingan konseling dalam mempermudah guru bk dalam mendata siswa yang bermasalah disekolah dan siswa yang berkonsultasi melalui sistem. Sistem Informasi ini dapat memberikan informasi mengenai pembuatan suatu sistem informasi bimbingan konseling yang terkoneksi dengan WA gateway dan memberikan konsultasi apakah terdapat siswa yang bermasalah atau tidak.

Dari hasil penelitian yang telah dilakukan, baik dalam hal penelitian maupun pengerjaan serta pembuatan sistem informasi bimbingan konseling yang terkoneksi dengan WA gateway terdapat beberapa saran yaitu sebelum sistem ini dijalankan, guru bk dan siswa harus diberikan penjelasan dengan baik mengenai proses kerja sistem yang akan ditampilkan sehingga tidak tejadi kesalahan. Sistem informasi bimbingan konseling yang terkoneksi dengan WA gateway harus didukung dengan sistem yang disiplin dan peraturan yang baik sesuai ketetapan bersama agar berjalan dengan bagaimana semestinya. Sistem informasi bimbingan konseling yang terkoneksi dengan WA gateway ini dapat dikembangkan kembali dalam hal desain atau penambahan database sesuai kebutuhan pemeliharaan data sistem informasi ini.

\section{UCAPAN TERIMAKASIH}

Ucapan terima kasih kepada semua pihak, terutama kepada Sekolah MTs Al-Husna Depok yang memberi kesempatan untuk studi kasus penelitian ini.

\section{DAFTAR PUSTAKA}

Hendini, A. (2016). Pemodelan UML Sistem Informasi Monitoring Penjualan Dan Stok Barang (Studi Kasus: Distro Zhezha Pontianak). Jurnal Khatulistiwa Informatika, 4(2), 107-116.

Hidayatullah, Priyanto, \& Kawistara, J. K. (2017). Pemrograman WEB. Informatika Bandung.

Kristanto, A. (2018). Perancangan Sistem Informasi dan Aplikasinya. Gava Media.

Rosa, A. S., \& Shalahuddin, M. (2018). Rekayasa Perangkat Lunak Terstruktur dan Berorientasi Objek. Informatika.

Sianipar, R. H. (2017). Dasar Pemrograman JavaScript Langkah Demi Langkah. ANDI.

Subhan, M. (2012). Analisa Perancangan Sistem. Lentera Ilmu Cendikia.

Susanto, A. (2018). Bimbingan dan Konseling di Sekolah: Konsep, Teori, dan Aplikasinya. Kencana.

Sugiyono. (2016). Metode Penelitian Kuantitatif, Kualitatif, Dan $R \& D$. Pt Alfabet.

Yakub. (2012). Pengantar Sistem Informasi. Graha Ilmu.

Yenda, P. (2016). Trik Cepat Membangun Aplikasi Berbasis Web dengan Framework CodeIgniter. Andi Offset.

Zheng, J., Feng, Y., \& Zhao, Y. (2014). A Unified Modeling Language-Based Design And Application For A Library Management Information System. Cybernetics and Information Technologies, 14(5), 129-144. 